\title{
Serodiagnosis of Zika virus (ZIKV) infections by a novel NS1-based ELISA devoid of cross-reactivity with dengue virus antibodies: a multicohort study of assay performance, 2015 to 2016
}

K Steinhagen ${ }^{1}$, C Probst ${ }^{1}$, C Radzimski ${ }^{1}$, J Schmidt-Chanasit ${ }^{23}$, P Emmerich ${ }^{2}$, M van Esbroeck ${ }^{4}$, J Schinkel 5 , MP Grobusch ${ }^{6} 7$ , A Goorhuis ${ }^{6}$, JM Warnecke ${ }^{1}$, E Lattwein ${ }^{1}$, L Komorowski ${ }^{1}$, A Deerberg ${ }^{1}$, S Saschenbrecker ${ }^{1}$, W Stöcker ${ }^{1}$, W Schlumberger ${ }^{1}$ 1. Institute for Experimental Immunology, EUROIMMUN AG, Lübeck, Germany

2. WHO Collaborating Centre for Arbovirus and Haemorrhagic Fever Reference and Research, Bernhard-Nocht Institute for Tropical Medicine, Hamburg, Germany

3. German Center for Infection Research (DZIF), Partner Site Hamburg-Lübeck-Borstel, Hamburg, Germany

4. National Reference Center for Arboviruses, Department of Clinical Sciences, Institute of Tropical Medicine, Antwerp, Belgium

5. Department of Medical Microbiology, Section of Clinical Virology, Academic Medical Center, Public Health Service, Amsterdam, the Netherlands

6. Center for Tropical Medicine and Travel Medicine, Department of Infectious Diseases, Division of Internal Medicine, Academic Medical Center, University of Amsterdam, Amsterdam, the Netherlands

7. Institute of Tropical Medicine, University of Tübingen, Tübingen, Germany

Correspondence: Wolfgang Schlumberger (w.schlumberger@euroimmun.de)

Citation style for this article:

Steinhagen K, Probst C, Radzimski C, Schmidt-Chanasit J, Emmerich P, van Esbroeck M, Schinkel J, Grobusch MP, Goorhuis A, Warnecke JM, Lattwein E, Komorowski L, Deerberg A, Saschenbrecker S, Stöcker W, Schlumberger W. Serodiagnosis of Zika virus (ZIKV) infections by a novel NS1-based ELISA devoid of cross-reactivity with dengue virus antibodies: a multicohort study of assay performance, 2015 to 2016. Euro Surveill. 2016;21(50):pii=30426. DOI: http://dx.doi.0rg/10.2807/15607917.ES.2016.21.50.30426

Serological diagnosis of Zika virus (ZIKV) infections is challenging due to high cross-reactivity between flaviviruses. We evaluated the diagnostic performance of a novel anti-ZIKV ELISA based on recombinant ZIKV non-structural protein 1 (NS1). Assay sensitivity was examined using sera from 27 patients with reverse transcription (RT)-PCR-confirmed and 85 with suspected ZIKV infection. Specificity was analysed using sera from 1,015 healthy individuals. Samples from 252 patients with dengue virus $(n=93)$, West Nile virus $(n=34)$, Japanese encephalitis virus $(n=25)$, chikungunya virus $(n=19)$ or Plasmodium spp. $(n=69)$ infections and from 12 yellow fever-vaccinated individuals were also examined. In confirmed ZIKV specimens collected $\geq 6$ days after symptom onset, ELISA sensitivity was $58.8 \%$ (95\% confidence interval (CI): 36.0-78.4) for IgM, 88.2\% (95\% Cl: 64.4-98.0) for IgG, and $100 \%$ (95\% Cl: $78.4-100)$ for IgM/IgG, at $99.8 \%(95 \% \mathrm{Cl}$ : 99.2-100) specificity. Cross-reactivity with high-level dengue virus antibodies was not detected. Among patients with potentially cross-reactive antibodies anti-ZIKV positive rates were $0.8 \%$ (95\% Cl: 0-3.0) and $0.4 \%(95 \% \mathrm{Cl}: 0-2.4)$ for IgM and IgG, respectively. Providing high specificity and low cross-reactivity, the NS1-based ELISA has the potential to aid in counselling patients, pregnant women and travellers after returning from ZIKV-endemic areas.

\section{Introduction}

Zika virus (ZIKV) is an emerging mosquito-transmitted flavivirus currently causing large epidemics in South and Central America as well as in the Caribbean, presenting a global public health emergency [1]. It is closely related to other human pathogenic members of the flavivirus family such as dengue virus (DENV), West Nile virus (WNV), Japanese encephalitis virus (JEV) and yellow fever virus (YFV). Besides their structural resemblance, most of these viruses share a partially overlapping geographical distribution, with tropical and subtropical regions representing the favourable environment of the main vector, mosquitos of the genus Aedes [2].

The diagnosis of ZIKV infections is increasingly relevant for European countries where, up to now, only a small number of travellers returning from endemic areas have contracted the virus [3]. However, there are concerns that ZIKV might be imported by infected individuals and spread through sexual transmission and via Aedes mosquitos that are endemic in parts of southern Europe.

The clinical symptoms associated with ZIKV infection include fever, rash, arthralgia, myalgia and conjunctivitis, and are normally self-limiting. The proportion of asymptomatic ZIKV infections is still unknown, but there is evidence that infection may go unrecognised 


\section{FIGURE 1}

Anti-ZIKV reactivity in patients with RT-PCR-confirmed $(n=27)$ and suspected $(n=85)$ ZIKV infection as determined by ELISA for (A) IgM and (B) IgGa ; time course analysis of anti-ZIKV antibody levels in follow-up samples from (C) a German patient returning from Colombia (probable primary ZIKV infection) ${ }^{\mathrm{b}}$ and (D) a Colombian patient with RT-PCR-confirmed ZIKV infection (probable secondary flavivirus infection)

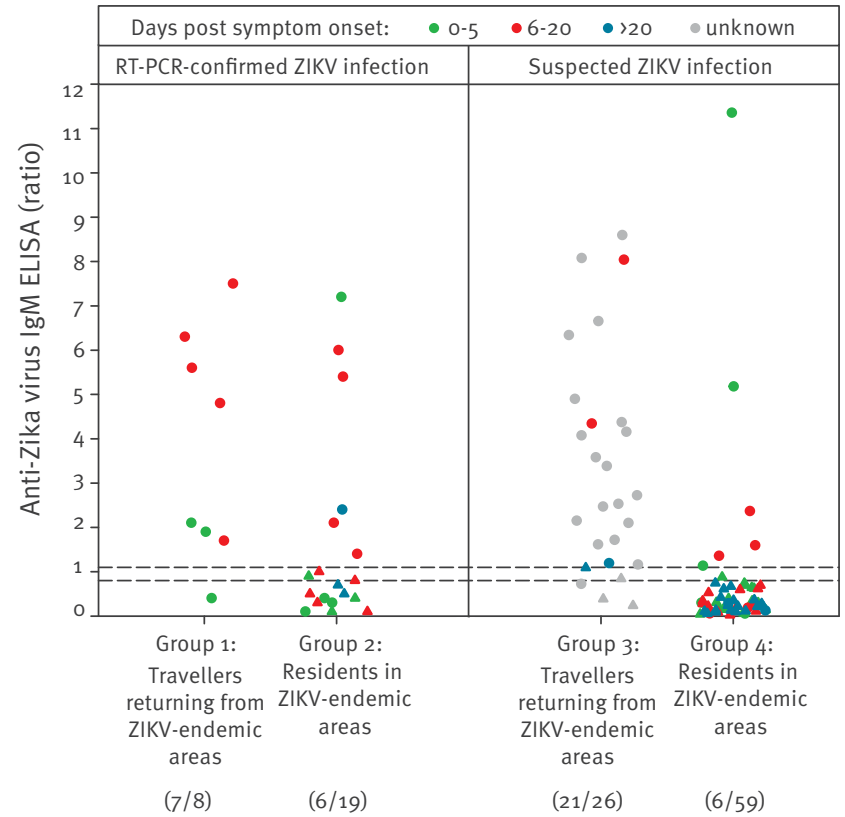

C.

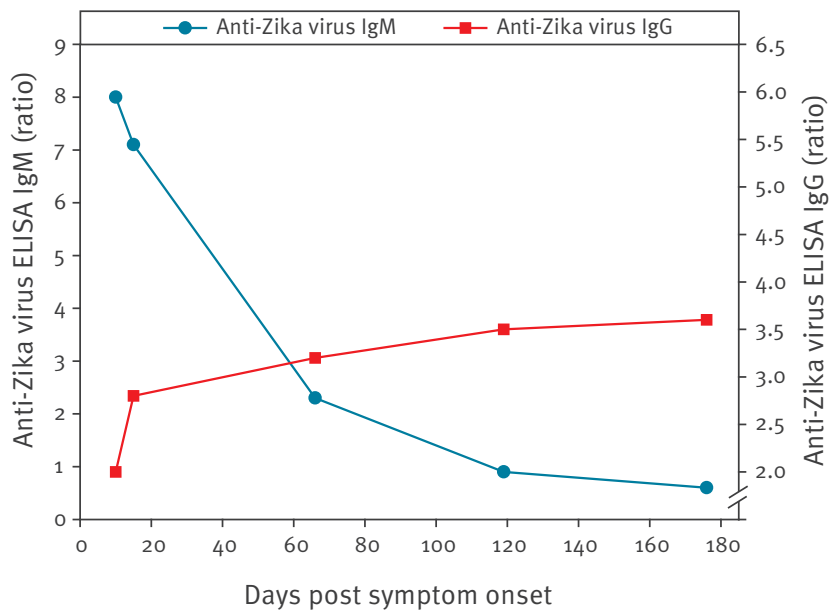

B.

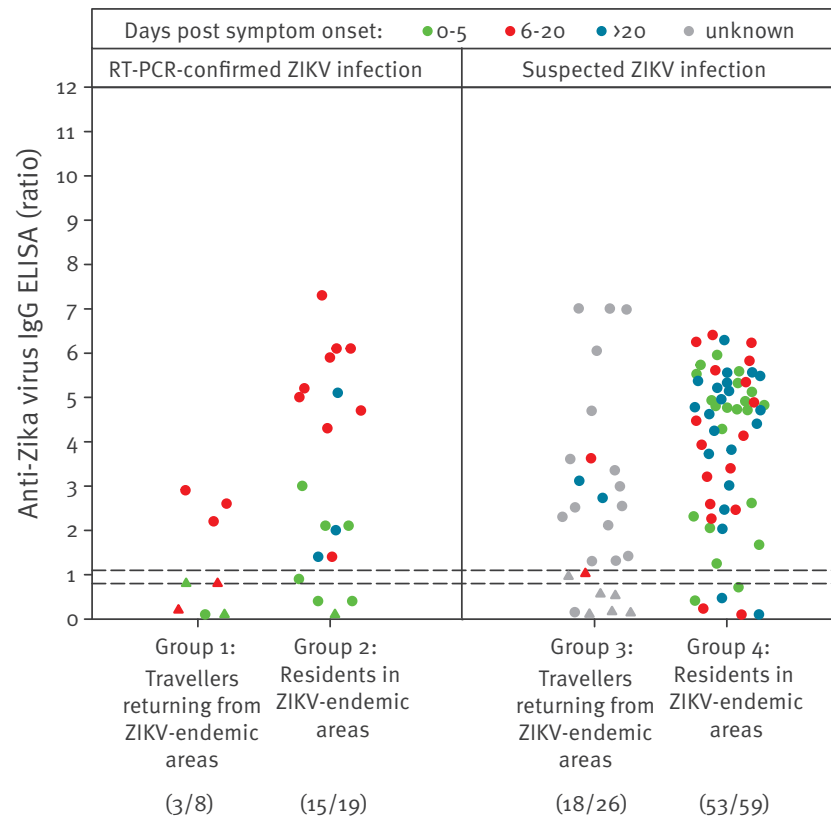

D.

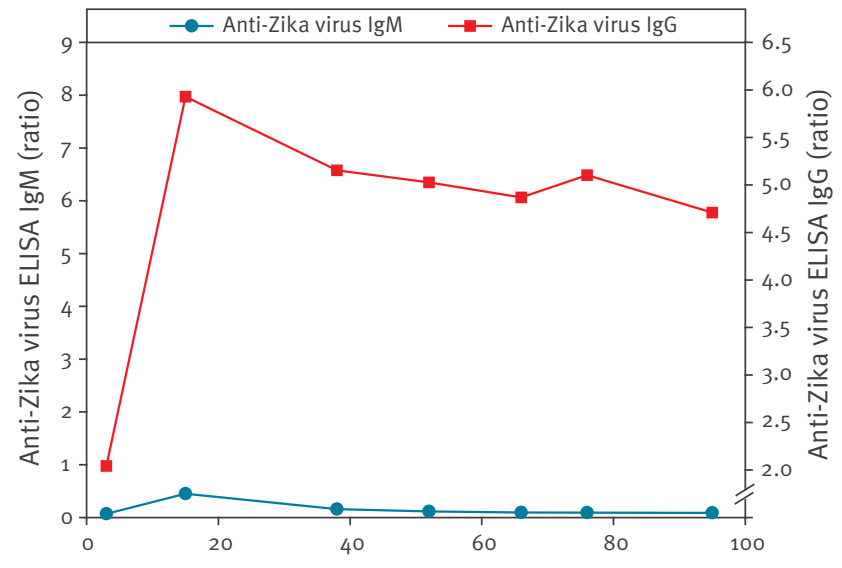

Days post symptom onset

RT-PCR: reverse transcription-PCR; US: United States; WHO: World Health Organization; ZIKV: Zika virus.

a Per patient, one sample was examined for anti-ZIKV IgM and IgG antibodies. Plotted data points represent ratio values (extinctionsample/ extinctioncalibrator). Cut-off values for borderline results $(\geq 0.8$ to $<1.1)$ and positive results $(\geq 1.1)$ are indicated by horizontal dashed lines. Positive and total cases are indicated in parentheses. Triangles indicate samples with a ratio for anti-ZIKV IgM or IgG below the cut-off («1.1), but a corresponding positive result in IgG or IgM testing, respectively.

b Samples were provided by the WHO Collaborating Centre for Arbovirus and Haemorrhagic Fever Reference and Research, Hamburg, Germany. Cut-off ratio: $\geq 1.1$

c Samples were provided by Biomex US LLC, Coconut Creek, Florida, US. Cut-off ratio: $\geq 1.1$. 


\section{FIGURE 2}

Anti-ZIKV reactivity in potentially cross-reactive samples $(\mathrm{n}=252)$ and healthy controls $(\mathrm{n}=1,015)$ as determined by ELISA for (A) IgM and (B) IgG ${ }^{\mathrm{a}, \mathrm{b}}$, study evaluating a novel NS1-based ELISA, Germany $2016^{*}$

A.

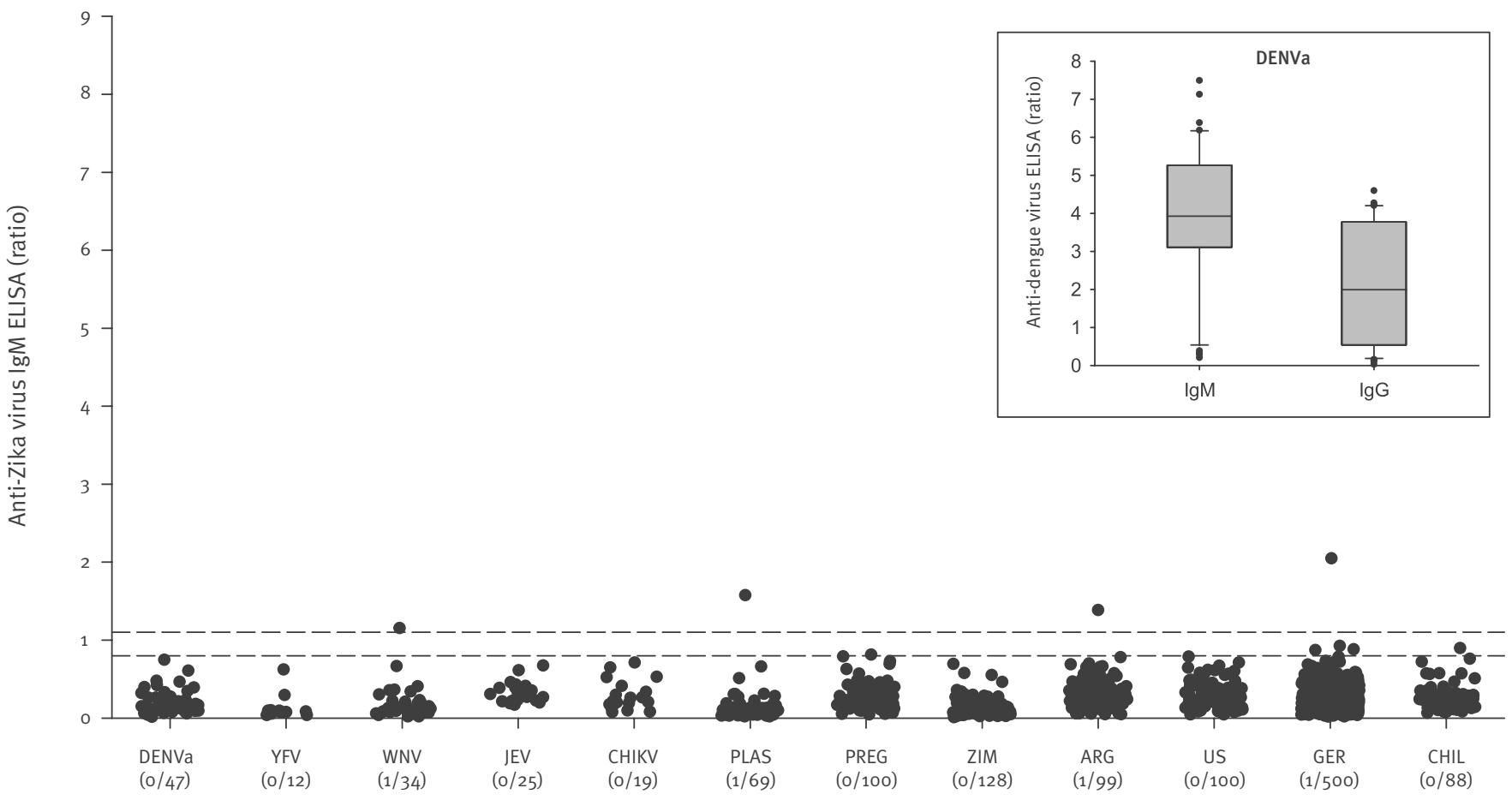

B.

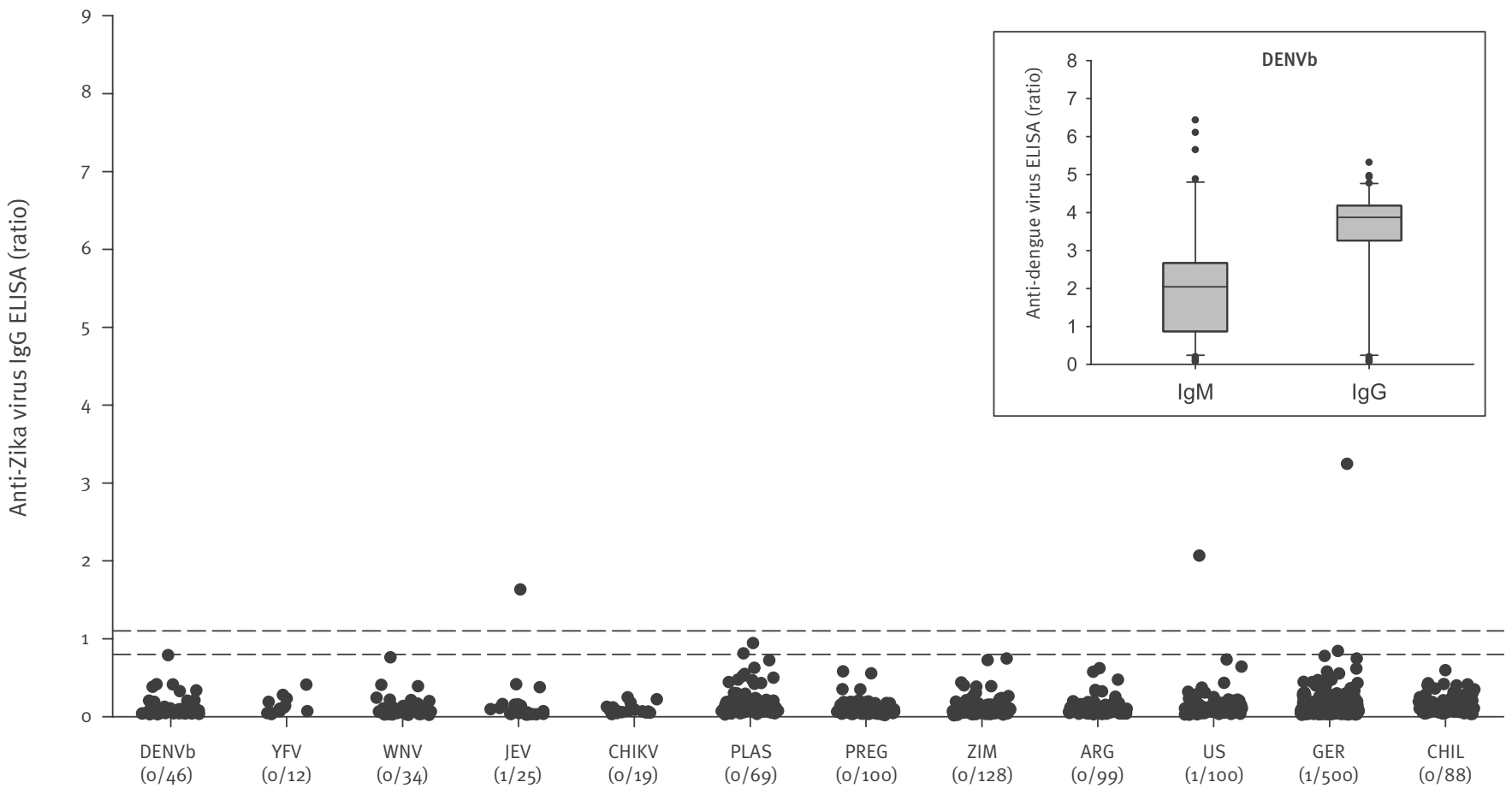

ARG: Argentina; CHIKV: chikungunya virus; CHIL: children; DENV: dengue virus; GER: Germany; JEV: Japanese encephalitis virus; NS: non-structural protein; PLAS: Plasmodium; PREG: pregnant women; US: United States; WNV: West Nile virus; YFV: Yellow fever virus; ZIKV: Zika virus; ZIM: Zimbabwe.

a Plotted data points represent ratio values (extinctionsample/extinctioncalibrator); one data point per patient. Cut-off values for borderline results ( $\geq 0.8$ to $<1.1$ ) and positive results $(\geq 1.1)$ are indicated by horizontal dashed lines. Positive and total cases are indicated in parentheses.

${ }^{b}$ To provide high levels of potentially cross-reactive anti-DENV IgM and IgG antibodies, the DENV-infected patients were divided into two groups: DENVa, high median ratio (3.9) anti-DENV IgM, anti-DENV IgM ratio $\geq 3.0$ in $79 \%$ of cases (inset Panel A); DENVb, high median ratio (3.9) anti-DENV IgG, anti-DENV IgG ratio $\geq 3.0$ in $80 \%$ of cases (inset Panel B). Cut-off ratio (anti-DENV ELISA, EUROIMMUN): $\geq 1.1$ 
in a considerable number of cases $[1,4]$. In the acute phase, fever due to ZIKV infection is difficult to differentiate clinically from that due to DENV infections [5]. Chikungunya virus (CHIKV), belonging to the Togaviridae family, should also be considered in differential diagnostics, as it is transmitted by the same mosquito vector and circulates in the same regions [2]. The common distribution and similar clinical presentation, in combination with high variation in disease outcome of ZIKV-, DENV- and CHIKV-infected patients, highlight the need for specific and reliable diagnostic methods. Knowing the infecting virus can be of clinical relevance, for example, when ZIKV infection is suspected in women during pregnancy, which could result in fetal malformations, or in men who could transmit the virus sexually, or, in cases of CHIKV infection with prolonged arthralgias, where correct diagnosis can help avoid unnecessary rheumatological analysis.

The current ZIKV epidemic, particularly in Brazil, has revealed two potential complications in ZIKV infections, which were initially suspected during the 2007 outbreak in Micronesia [6]. Firstly, a large rise in the number of cases of Guillain-Barré syndrome (GBS), an autoimmune disease resulting from damage of peripheral-nerve myelin, was triggered by ZIKV infections $[1,7]$. Secondly, a strong causative link was suggested between fetal abnormalities and ZIKV infection during early pregnancy, based on a 20 -fold increase in newborn microcephaly in highly endemic regions in Brazil, followed by the first reports of ZIKV genome detection in amniotic fluid and fetal brain after intrauterine diagnosis of microcephaly [1,8-10].

At present, diagnosis of ZIKV infections is challenging because the only specific tool is direct virus detection using nucleic acid-based testing (NAT), with ZIKV RNA detectable in serum up to 7 days after symptom onset and even longer in saliva, urine (about 20 days) and semen (>20 days) [6,11-13]. Plaque-reduction neutralisation tests (PRNTs) can measure virus-specific neutralising antibodies, a fact that is relevant in regions where two or more flaviviruses co-occur. However, PRNTs do not discriminate between antibody classes and, especially in secondary flavivirus infections, cross-reactive neutralising antibodies may contribute to virus neutralisation $[6,14,15]$, thus questioning the suitability of PRNTs for the confirmation of active infection. In addition, PRNTs are time-consuming, difficult to perform, not suitable for testing large panels, and therefore restricted to highly specialised laboratories. In contrast, ELISA-based measurement is a rapid, scalable and technically mature approach. IgM antibodies against flavivirus antigens are first produced 4 to 7 days after infection, and IgG antibodies appear a few days later. However, a major limitation of current ELISAs for diagnosing flaviviral infections is their extensive crossreactivity within the Flavivirus genus [6].

The molecular organisation of flaviviruses is conserved. Virions consist of single-stranded positive
RNA surrounded by an icosahedral capsid and envelope. The RNA encodes for a single polyprotein, which is processed into structural (C, prM, and E) and nonstructural (NS1 to NS5) proteins [16]. Knowledge about $\mathrm{NS}_{1}$ is mainly derived from the well-studied flaviviruses (DENV, WNF, YFV), whereas little is known about NS1 from ZIKV. NS1 proteins (molecular mass 46-55 kDa) are present in two distinct variants [17]. Membrane-associated NS1 is mainly found as a dimer that interacts with intracellular membranes, such as the endoplasmic reticulum and vesicle packets, and with the cell surface $[18,19]$. Secreted NS1 assembles into barrel-shaped hexamers consisting of three dimers $[20,21]$. The NS1 function remains elusive, although roles in RNA replication [18], intracellular protein transport, virion release [22] and immunomodulatory activities [17] have been proposed. As reported for DENV and WNV, NS1 is secreted by infected cells into the bloodstream [23,24], stimulating the immune system to produce high NS1 antibody titres. However, acutephase release of ZIKV-NS1 into patient's serum has not yet been verified, and a ZIKV-NS1 antigen assay is currently not available [25]. Recombinant NS1 proteins were used in a multiplex serological protein microarray for the detection of anti-DENV, -WNV, and -JEV IgM and IgG, demonstrating high sensitivity and limited crossreactivity, suggesting NS1 may represent an efficient antigenic substrate [26].

Recently, an ELISA based on recombinant ZIKV-NS1 has been developed [27]. Here, the diagnostic performance of this assay was examined using sera from returning travellers and patients from ZIKV-endemic areas with laboratory-confirmed ZIKV infection, potentially crossreactive samples from patients with flaviviral and other infections, as well as control panels from blood donors of different ages and geographical origin.

\section{Methods}

\section{Human sera}

The study included serum samples from 27 patients who had tested positive for ZIKV RNA by reverse transcription PCR (RT-PCR); Group 1: travellers returning from endemic areas $(n=8)$; Group 2: residents in ZIKVendemic areas $(n=19)$. On the basis of direct detection of the pathogen's genome, these cases were referred to as having RT-PCR-confirmed ZIKV infection. Samples from a further 85 patients had been pre-characterised by anti-ZIKV indirect immunofluorescence assay (IIFA; EUROIMMUN, Lübeck, Germany) based on whole virus antigen, showing reactivity for anti-ZIKV IgM and/or IgG; Group 3: travellers returning from endemic areas $(n=26)$; Group 4: residents in ZIKV-endemic areas $(n=59)$. Since false-positive results due to cross-reactivity of this IIFA cannot be excluded, these cases were referred to as having suspected ZIKV infection (Table 1).

Classification into three stages of ZIKV infection was according to the Pan American Health Organization 


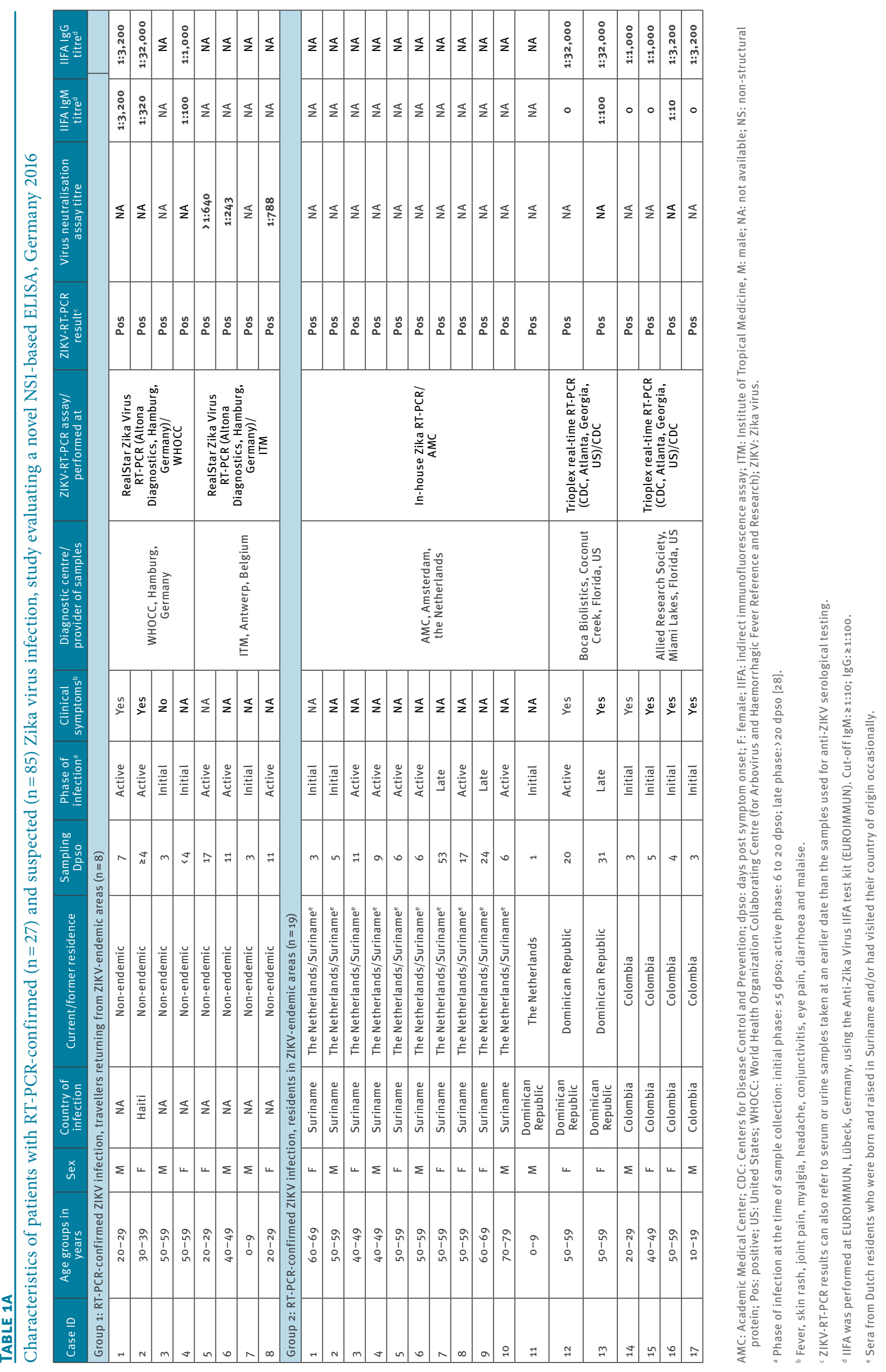




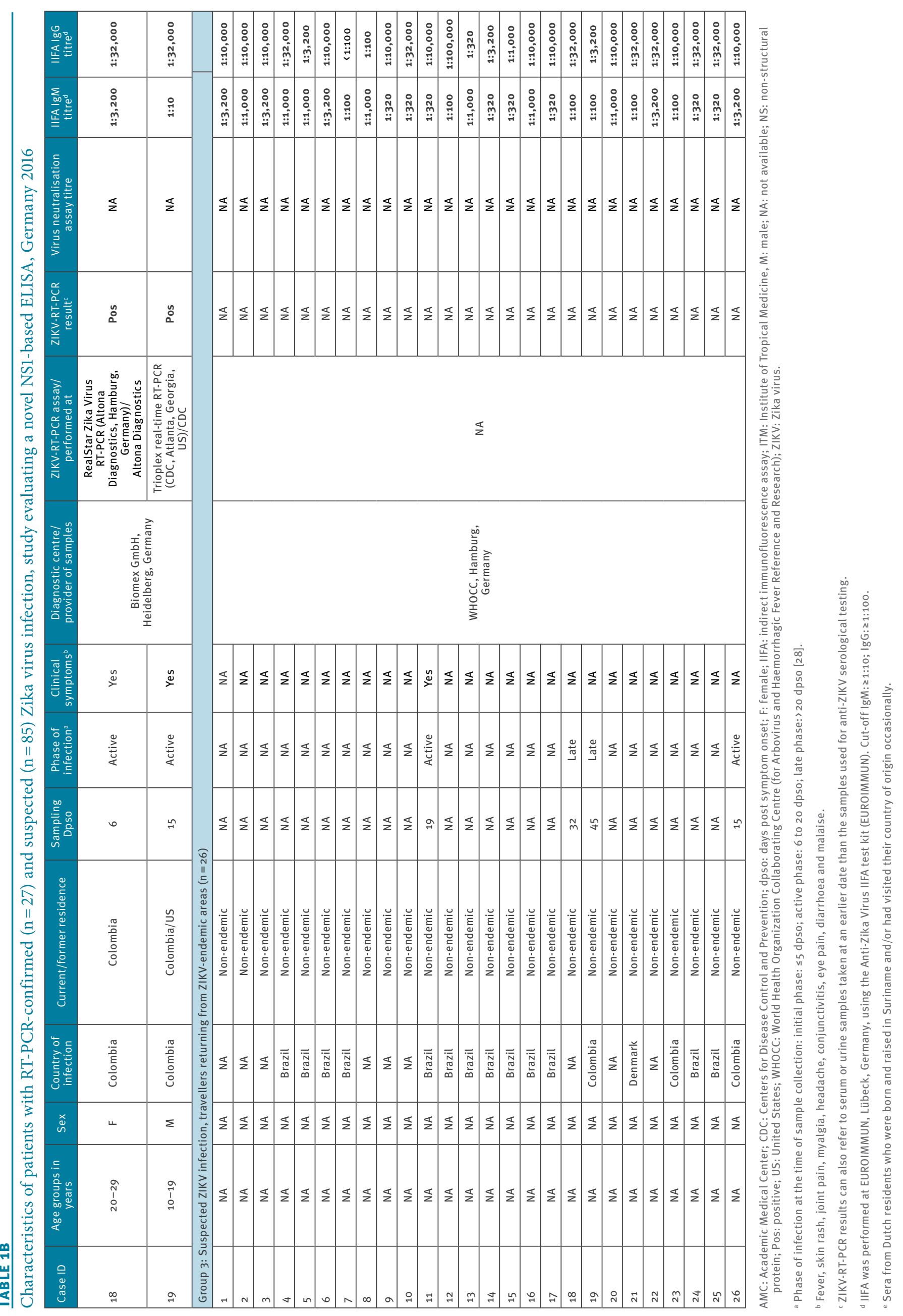



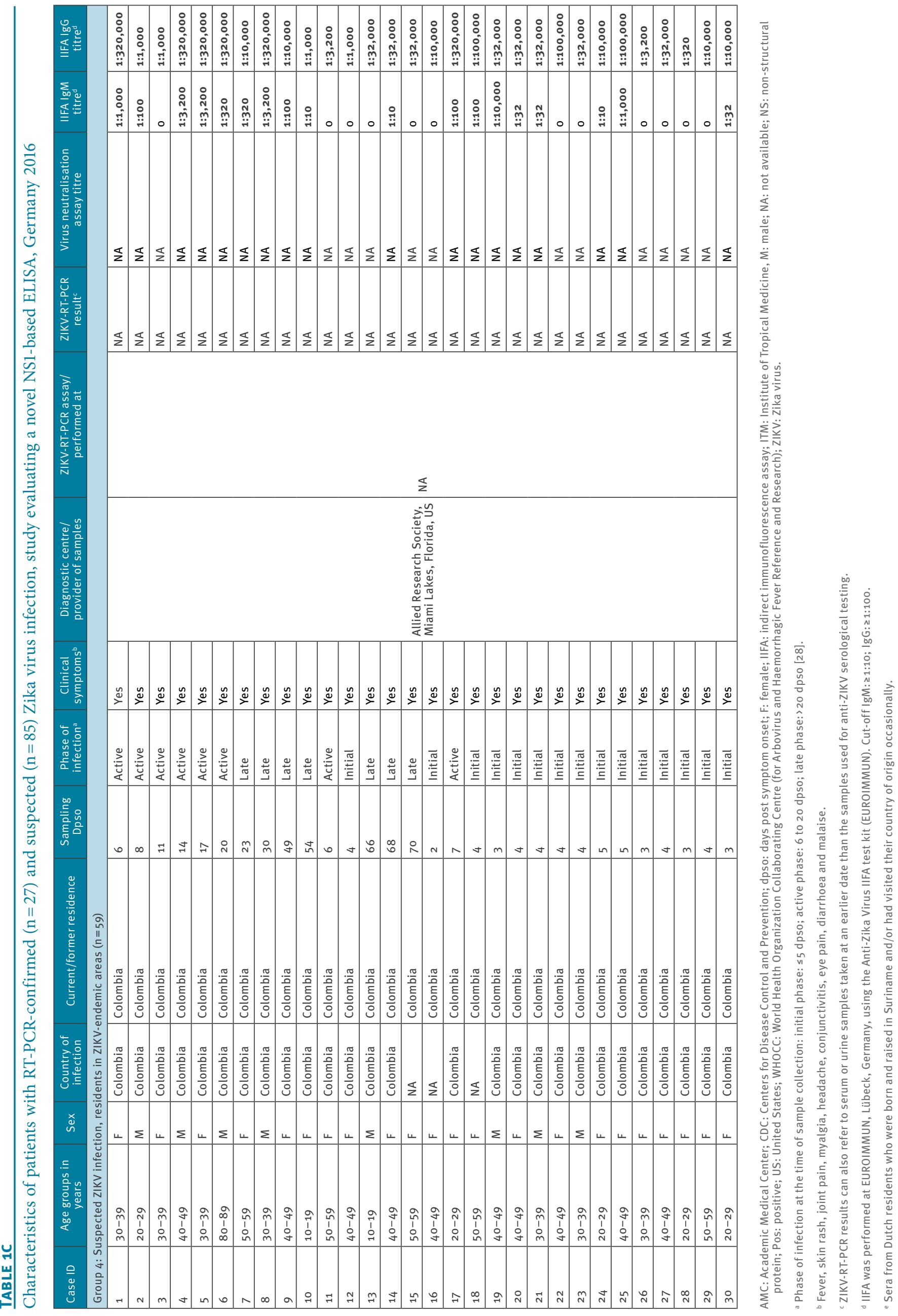

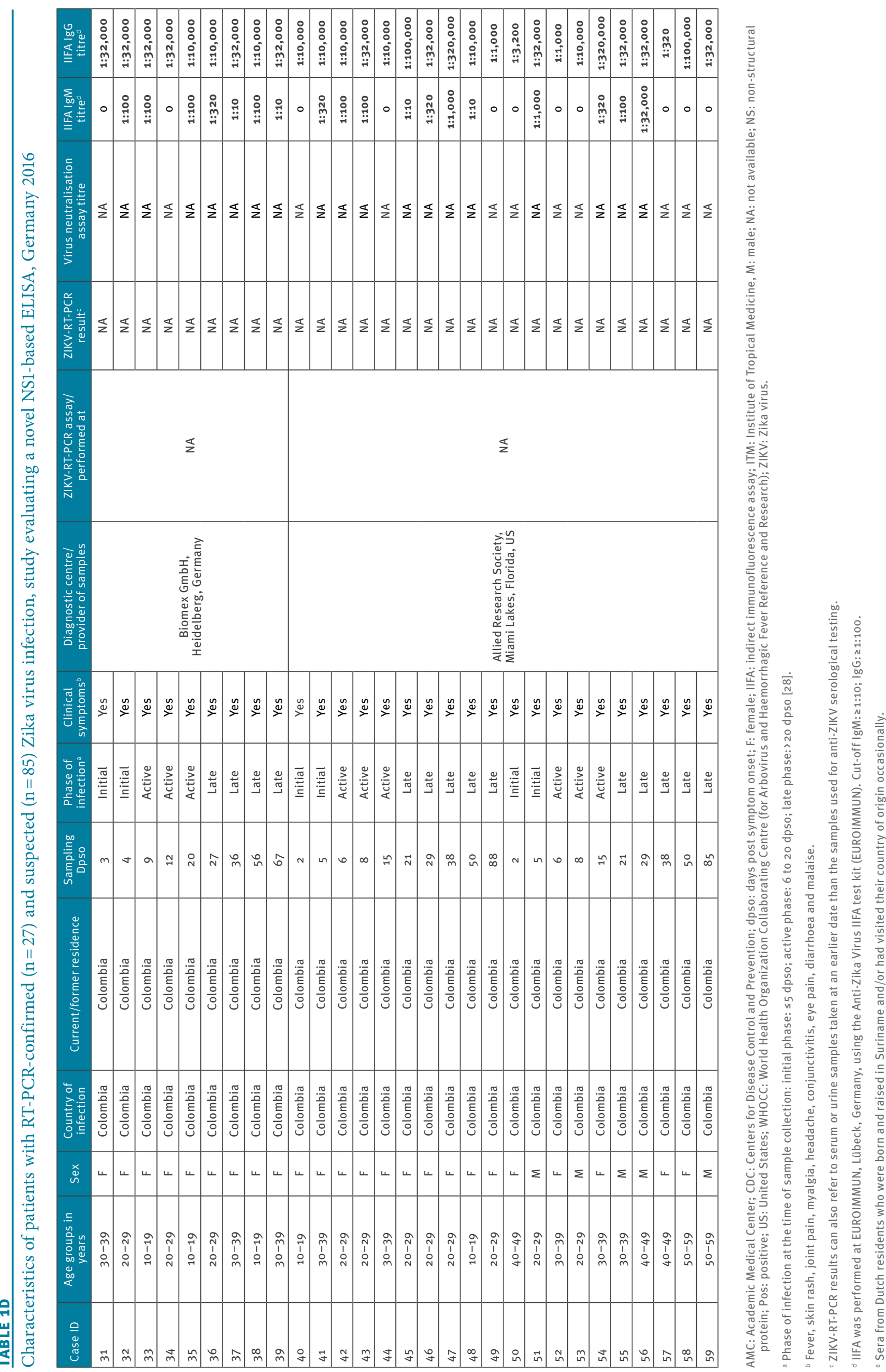
(PAHO) /World Health Organization (WHO) recommendations on ZIKV surveillance in the Americas [28]: $\leq 5$ days post symptom onset, initial stage; $6-20$ days post symptom onset, active stage; 20 days post symptom onset, late stage. Samples from travellers returning from endemic areas were provided by the diagnostic institutes (listed in Table 1) to which they had been sent for routine diagnostic testing. Samples from patients residing in Latin America (i.e. Dominican Republic and Colombia) were purchased from Boca Biolistics (Coconut Creek, Florida, United States (United States (US)), Allied Research Society (Miami Lakes, Florida, US) and Biomex GmbH (Heidelberg, Germany). As confirmed by these institutes and companies, written informed consent had been obtained from all patients, and there were no legal or ethical restrictions to using the samples.

To evaluate cross-reactivity, samples were used from 252 patients with either a post-YFV vaccination status $(n=12)$, or with other flaviviral $(D E N V=93 ; W N V=34$, JEV = 25), non-flaviviral (CHIKV $=19)$ and Plasmodium spp. (PLAS: $n=69$ ) infections. In samples from DENVinfected patients, the confirmation of DENV as the infectious agent was based on NS1 antigen detection [28]. Sera from 1,015 healthy individuals (pregnant women, blood donors and children) living in flavivirus-endemic and non-endemic areas served as negative controls. Pre-characterisation data for all control cohorts are reported in Table 2. To the best of the authors' knowledge, none of these samples were analysed in previous studies.

Specimens, anamnestic/clinical information and precharacterisation data were provided anonymised to the Institute for Experimental Immunology (affiliated to EUROIMMUN). All sera were stored at $-20^{\circ} \mathrm{C}$ until assayed. The study was performed according to the recommendations of the Central Ethical Committee of Germany [29].

\section{Enzyme-linked immunosorbent assays}

Anti-Zika Virus IgM and IgG ELISA (EUROIMMUN) were used as recommended by the manufacturer. These kit assays are based on standardised reagents and microtitre plates coated with recombinant ZIKV-NS1. Briefly, sera diluted 1:101 in sample buffer were added to the wells and allowed to react for $60 \mathrm{~min}$ at $37^{\circ} \mathrm{C}$. Before IgM detection, sera were pre-incubated with sample buffer containing IgG/rheumatoid factor (RF) absorbent (EUROIMMUN) to remove class IgG antibodies and class IgM RF from the sample. This step prevents specific IgG from displacing IgM from the antigen (leading to false IgM-negative results) and RF-IgM from reacting with specifically bound IgG (leading to false IgMpositive results). Bound antibodies were detected by applying goat anti-human IgM peroxidase conjugate or rabbit anti-human IgG peroxidase conjugate for 30 min at room temperature, followed by staining with tetramethylbenzidine for $15 \mathrm{~min}$. The enzymatic reaction was stopped by addition of one volume $0.5 \mathrm{~mol} / \mathrm{L}$ sulphuric acid. A calibrator (chicken-human chimeric ZIKV antibody with a concentration adjusted to give an extinction value defining the upper limit of the reference range of non-infected persons) as well as positive and negative controls were provided with the test kit and assayed with each test run. Colour intensity of the enzymatic reactions was determined photometrically at $450 \mathrm{~nm}$ (reference $620 \mathrm{~nm}$ ), resulting in extinction values. A signal-to-cut-off ratio (extinctionsample/ extinctioncalibrator) was calculated for each sample.

Receiver-operating characteristics (ROC) analysis based on the initial validation dataset of positive and negative samples was done by the manufacturer to evaluate assay performance at each possible cut-off, demonstrating optimal sensitivity and specificity at ratio values of $0.8(\mathrm{lgM})$ and $0.6(\mathrm{ggG})$. To ensure high specificity, the borderline range $(\geq 0.8$ to $<1.1)$ was established between the highest negative and the lowest positive validation sample, resulting in a positivity cut-off of $\geq 1.1$.

\section{Anti-dengue Virus IgM and IgG ELISA (EUROIMMUN)} were used.

\section{Statistics}

Statistical analyses were performed using GraphPad Prism 6 (GraphPad Software Inc., La Jolla, California, US) and SigmaPlot 13.0 (SSI, San Jose, California, US). Sensitivity was calculated as the proportion of ZIKV patients (referring to groups 1 to 4 as indicated) identified as positive by the assay. Specificity was calculated as the proportion of negative test results obtained among healthy controls. We calculated 95\% confidence intervals (Cls) according to the modified Wald method. The study was performed in compliance with the Standards for Reporting of Diagnostic accuracy (STARD) statement [30].

\section{Results}

\section{Sensitivity of the enzyme-linked \\ immunosorbent assay}

The sensitivity of the novel NS1-based anti-ZIKV ELISA was evaluated in sera from 27 patients with RT-PCRconfirmed ZIKV infection that had been sub-grouped into travellers returning from ZIKV-endemic areas and endemic-area residents. Among eight infected travellers returning from ZIKV-endemic areas (group 1), positive anti-ZIKV IgM and IgG reactivity was found in seven $(87.5 \%)$ and three $(37.5 \%)$ cases, respectively. Of 19 infected residents in endemic-areas (group 2), six $(31.6 \%)$ were positive for anti-ZIKV IgM and 15 (79.0\%) for IgG. In addition, sera from 85 patients with suspected ZIKV infection were examined. Here, of 26 infected travellers returning from ZIKV-endemic areas (group 3) $21(80.8 \%)$ were positive for anti-ZIKV IgM and $18(69.2 \%)$ for $\lg G$, while among 59 infected residents in endemic-areas (group 4), six (10.2\%) showed positive reactivity for anti-ZIKV IgM and 53 (89.9\%) for IgG. For the total of RT-PCR-confirmed and suspected 

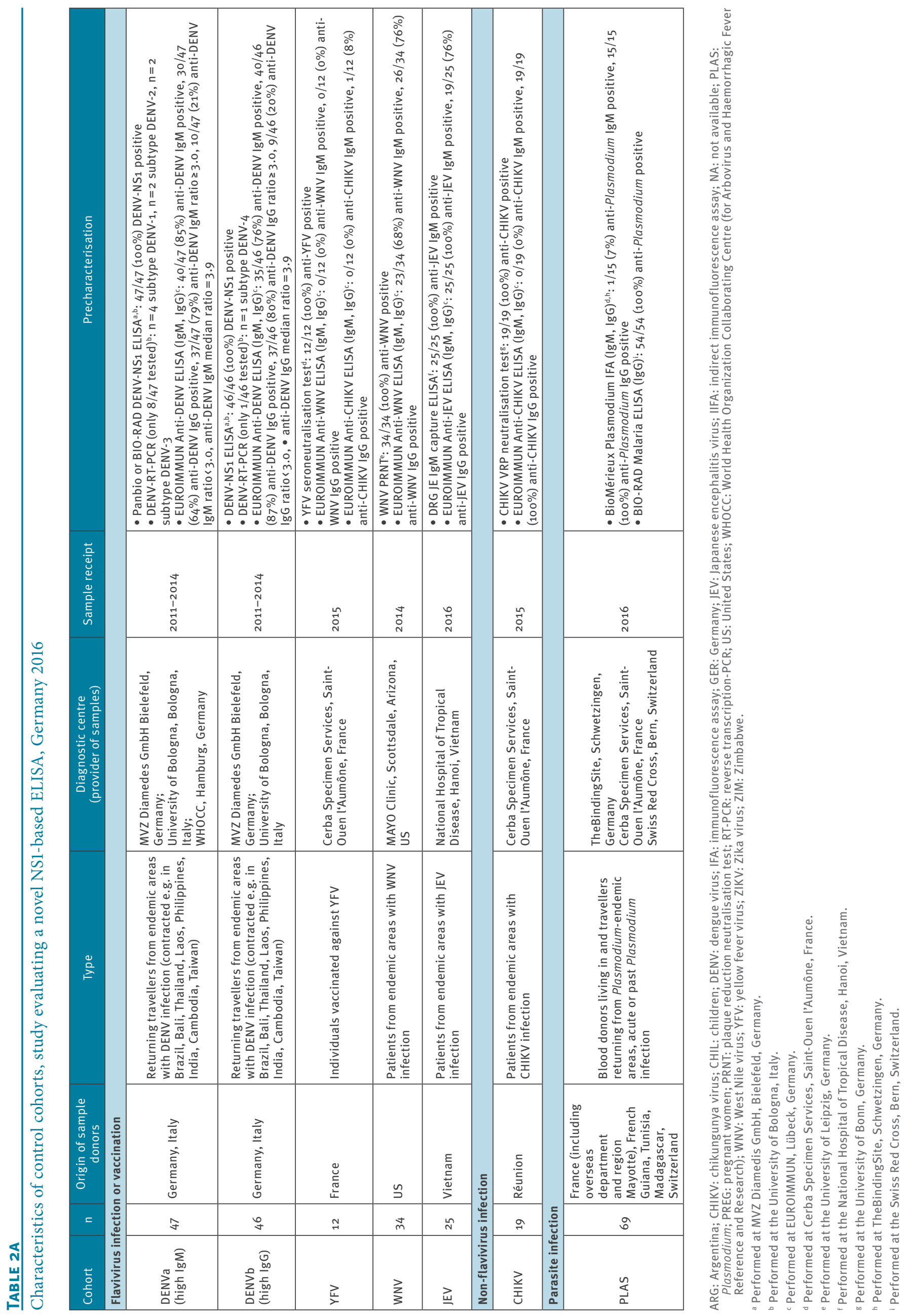


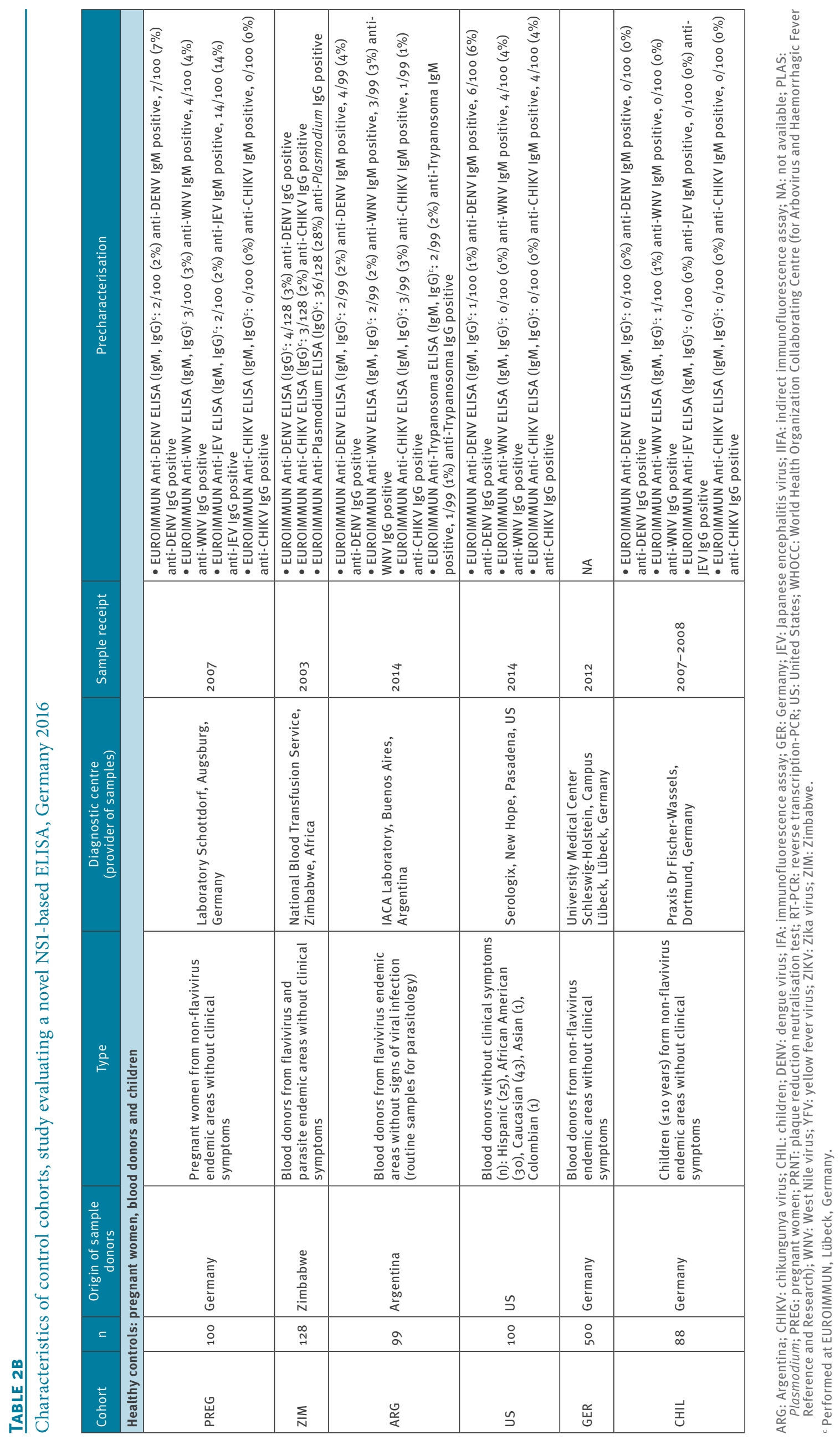


cases, the combined ELISA sensitivity (IgM and/or $\mathrm{IgG}$ ) amounted to $23 / 27(85.2 \%)$ and $78 / 85$ (91.8\%), respectively.

Confining the time point of serological evaluation to the active and late phase of ZIKV infection, i.e. $\geq 6$ days after symptom onset, anti-ZIKV IgM reactivity was observed in $10 / 17$ (58.8\%) patients with positive ZIKVRT-PCR and $3 / 38$ (7.9\%) patients with suspected ZIKV infection, while anti-ZIKV IgG was detectable in $15 / 17$ (88.2\%) and $34 / 38$ (89.5\%) cases, respectively. Thus, the combined sensitivity (IgM and/or $\operatorname{lgG}$ ) reached $17 / 17$ (100\%) among RT-PCR-confirmed cases and $34 / 38$ (89.5\%) among suspected cases (Table 3).

Comparing ZIKV-infected travellers returning from endemic areas (groups 1 and 3) with infected residents in these areas (groups 2 and 4), a tendency of distinct ZIKV antibody kinetics could be observed: in most returning travellers, high IgM ratio values (median 5.6; interquartile range (IQR): 4.6-6.9,) and moderate IgG ratios (median 2.2; IQR 0.9-2.8,) were detectable in the active phase of infection (cut-off ratio: 1.1). By contrast, the majority of endemic-area residents had infections with very high IgG ratios (median 4.8; IQR 3.3-5.9) during the active phase, while IgM ratios were variable, but predominantly negative or low (median 0.5; IQR 0.2-1.3) (Figure 1A and 1B).

Time course analysis of a German patient who showed clinical symptoms after returning from a stay in Colombia revealed very high anti-ZIKV IgM ratios on first testing (day 10 after symptom onset), while IgG ratios increased to moderate levels during the acute phase of infection and thereafter (Figure ${ }_{10} \mathrm{C}$ ). On the other hand, follow-up samples taken from a Colombian resident with RT-PCR-confirmed ZIKV infection indicated a significant rise in the ZIKV-specific IgG response between days 3 and 15 after symptom onset, followed by a slow decrease, while anti-ZIKV IgM was negative 3 days after symptom onset and remained below detection threshold for 14 weeks (Figure 1D).

\section{Cross-reactivity of the enzyme-linked}

immunosorbent assay

Cross-reactivity was analysed first in sera from 93 DENV-infected patients whose diagnosis had been secured by positive DENV-NS1 detection. This cohort was divided into one group (DENVa) with high antiDENV IgM (median ratio 3.9) and another group (DENVb) with high anti-DENV IgG (median ratio 3.9), ensuring the presence of high levels of potentially cross-reactive antibodies. In both groups, anti-ZIKV reactivity was below the threshold, indicating absence of cross-reactivity in these specimens. Further testing, on a supplementary basis, included 159 sera from patients positive for IgM and/or IgG against YFV, WNV, JEV, CHIKV or PLAS. Anti-ZIKV IgM was positive in $1 / 34$ (2.9\%) patients infected with WNV and $1 / 69$ (1.4\%) patients infected with PLAS. Anti-ZIKV IgG was found in $1 / 25(4.0 \%)$ patients infected with JEV (Figure 2 ). For the total of 252 potentially cross-reactive samples, the overall positivity rate amounted to $2 / 252$ (0.8\%) for IgM and $1 / 252$ (0.4\%) for IgG (Table 4 ).

\section{Specificity of the enzyme-linked immunosorbent assay}

Assay specificity was assessed by testing 1,015 sera from healthy controls. Only $1 / 99$ (1.0\%) Argentinian and $1 / 500$ (0.2\%) German blood donors were found anti-ZIKV IgM positive, while all 128 Zimbabwean and 100 US American blood donors as well as 100 German pregnant women and 88 children in Germany were negative. Anti-ZIKV IgG was present in 1/100 (1.0\%) US American and $1 / 500$ (0.2\%) German blood donors, but absent in the cohorts of Zimbabwean and Argentinian blood donors, pregnant women and children. Thus, overall specificity amounted to $99.8 \%$ for either Ig class (Table 4, Figure 2).

\section{Discussion}

The serological diagnosis of ZIKV infections has been challenging due to cross-reactions with other flaviviruses, secondary infections and previous vaccinations, which complicate interpretation, sometimes leading to unreliable or false-positive results $[6,31,32]$. Here, we evaluated a newly-developed ELISA with recombinant ZIKV-NS1 protein as solid-phase antigen. Huzly et al. recently provided evidence that this assay is highly specific, as demonstrated on a limited number of European patients with DENV, YFV, tick-borne encephalitis virus (TBEV) or hepatitis C virus infection [27]. In the present study, testing on specimens collected $\geq 6$ days after onset of symptoms (i.e. after the viraemic phase) revealed a combined sensitivity (IgM/IgG) of $100 \%$ for RT-PCR-confirmed cases of ZIKV infection at $99.8 \%$ specificity. Among suspected ZIKV cases, the combined sensitivity amounted to $89.5 \%$. Notably, we included only one serum sample for each of the studied patients in our analysis, except for the time course analysis. For the serological diagnosis of patients, however, the evaluation of follow-up samples is important and recommended to demonstrate seroconversion or a 4-fold increase in antibody titre [28]. In four of 27 RT-PCR-confirmed ZIKV cases, samples were negative for both IgM and IgG against ZIKV-NS1, presumably because all of them were taken only $\leq 4$ days after symptom onset, i.e. when antibodies had not yet reached detectable levels. Among 85 suspected ZIKV patients, too early sampling may account for two cases with negative $\lg M$ and $\lg G$, while the remaining five double-negative cases could be due to the absence of ZIKV infection (deficits in pre-characterisation) or to false-negative results.

Cross-reactivity with high-level DENV antibodies was not detectable and, according to preliminary analysis with a limited amount of samples, there was no indication for DENV serotype-dependent differences in cross-reactivity (data not shown). To better judge assay performance in endemic areas, samples from endemic residents who experienced multiple DENV (and other 
Anti-ZIKV reactivity in patients with RT-PCR-confirmed $(\mathrm{n}=27)$ and suspected $(\mathrm{n}=85)$ ZIKV infection as determined by ELISA for IgM and IgG, study evaluating a novel NS1-based ELISA, Germany 2016

\begin{tabular}{|c|c|c|c|c|c|c|c|c|c|c|}
\hline \multirow{2}{*}{ Group } & \multirow{2}{*}{ Characteristics } & & \multicolumn{4}{|c|}{$\begin{array}{c}\text { Anti-ZIKV ELISA reactivity } \\
\text { ( } \geq 1 \text { day post symptom onset) }\end{array}$} & \multicolumn{4}{|c|}{ 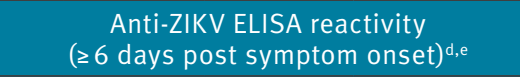 } \\
\hline & & & $n$ & $\lg M$ & $\lg G$ & $\lg \lg M /$ & $n$ & $\lg M$ & $\lg G$ & $\lg M / \lg G$ \\
\hline \multirow[b]{2}{*}{1} & \multirow{2}{*}{$\begin{array}{l}\text { RT-PCR-confirmed ZIKV } \\
\text { infection, travellers } \\
\text { returning from ZIKV- } \\
\text { endemic areas }\end{array}$} & Positive & 8 & 7 & 3 & 7 & 5 & 5 & 3 & 5 \\
\hline & & $\begin{array}{c}\text { Sensitivity } \\
\% \%^{\mathrm{b}} \\
(95 \% \mathrm{Cl}) \\
\end{array}$ & - & $\begin{array}{c}87.5 \\
(50.8-99.9)\end{array}$ & $\begin{array}{c}37 \cdot 5 \\
(13 \cdot 5-69.6)\end{array}$ & $\begin{array}{c}87.5 \\
(50.8-99.9)\end{array}$ & - & $\begin{array}{c}100 \\
(51.1-100)\end{array}$ & $\begin{array}{c}60.0 \\
(22.9- \\
88.4) \\
\end{array}$ & $\begin{array}{c}100 \\
(51.1-100)\end{array}$ \\
\hline \multirow[b]{2}{*}{2} & \multirow[b]{2}{*}{$\begin{array}{l}\text { RT-PCR-confirmed ZIKV } \\
\text { infection, residents in } \\
\text { ZIKV-endemic areas }\end{array}$} & Positive & 19 & 6 & 15 & 16 & 12 & 5 & 12 & 12 \\
\hline & & $\begin{array}{c}\text { Sensitivity } \\
\%{ }^{\mathrm{b}} \\
(95 \% \mathrm{Cl}) \\
\end{array}$ & - & $\begin{array}{c}31.6 \\
(15 \cdot 2-54 \cdot 2)\end{array}$ & $\begin{array}{c}78.9 \\
(56.1-92.1)\end{array}$ & $\begin{array}{c}84 \cdot 2 \\
(61.6-95 \cdot 3)\end{array}$ & - & $\begin{array}{c}41.7 \\
(19.3- \\
68.1) \\
\end{array}$ & $\begin{array}{c}100 \\
(71.8-100)\end{array}$ & $\begin{array}{c}100 \\
(71.8-100)\end{array}$ \\
\hline \multirow[t]{2}{*}{ Total $1+2$} & \multirow[b]{2}{*}{$\begin{array}{l}\text { RT-PCR-confirmed ZIKV } \\
\text { infection }\end{array}$} & Positive & 27 & 13 & 18 & 23 & 17 & 10 & 15 & 17 \\
\hline & & $\begin{array}{c}\text { Sensitivity } \\
\%^{\mathrm{b}} \\
(95 \% \mathrm{Cl})\end{array}$ & - & $\begin{array}{c}48.1 \\
(30.7-66.0)\end{array}$ & $\begin{array}{c}66.7 \\
(47.7-81.5)\end{array}$ & $\begin{array}{c}85.2 \\
(66.9-94 \cdot 7)\end{array}$ & - & $\begin{array}{l}58.8 \\
(36.0- \\
78.4)\end{array}$ & $\begin{array}{c}88.2 \\
\left(64.4^{-}\right. \\
98.0)\end{array}$ & $\begin{array}{c}100 \\
(78.4-100)\end{array}$ \\
\hline \multirow[b]{2}{*}{3} & \multirow[b]{2}{*}{$\begin{array}{l}\text { Suspected ZIKV infection, } \\
\text { travellers returning from } \\
\text { ZIKV-endemic areas }\end{array}$} & Positive & 26 & 21 & 18 & 25 & \multirow{2}{*}{\multicolumn{4}{|c|}{$\mathrm{NA}^{\mathrm{e}}$}} \\
\hline & & $\begin{array}{c}\text { Sensitivity } \\
\%^{\mathrm{b}} \\
(95 \% \mathrm{Cl})\end{array}$ & - & $\begin{array}{c}80.8 \\
(61.7-92.0)\end{array}$ & $\begin{array}{c}69.2 \\
(49.9-83.7)\end{array}$ & $\begin{array}{c}96.2 \\
(79.6-100)\end{array}$ & & & & \\
\hline \multirow[b]{2}{*}{4} & \multirow[b]{2}{*}{$\begin{array}{c}\text { Suspected ZIKV infection, } \\
\text { residents ZIKV-endemic } \\
\text { areas }\end{array}$} & Positive & 59 & 6 & 53 & 53 & 38 & 3 & 34 & 34 \\
\hline & & $\begin{array}{c}\text { Sensitivity } \\
\% \%^{\mathrm{b}} \\
(95 \% \mathrm{Cl})\end{array}$ & - & $\begin{array}{c}10.2 \\
(4.4-20.8)\end{array}$ & $\begin{array}{c}89.9 \\
(79.2-95.6)\end{array}$ & $\begin{array}{c}89.9 \\
(79.2-95.6)\end{array}$ & - & $\begin{array}{c}7.9 \\
(2.0-21.5)\end{array}$ & $\begin{array}{l}89.5 \\
(75 \cdot 3- \\
96.4)\end{array}$ & $\begin{array}{c}89.5 \\
(75 \cdot 3-96.4)\end{array}$ \\
\hline \multirow[t]{2}{*}{ Total $3+4$} & \multirow[b]{2}{*}{ Suspected ZIKV infection } & Positive & 85 & 27 & 71 & 78 & $38^{\mathrm{e}}$ & 3 & 34 & 34 \\
\hline & & $\begin{array}{c}\text { Sensitivity } \\
\% \%^{b} \\
(95 \% \mathrm{Cl})\end{array}$ & - & $\begin{array}{c}31.8 \\
(22.8-42.3)\end{array}$ & $\begin{array}{c}83.5 \\
(74.1-90.1)\end{array}$ & $\begin{array}{c}91.8 \\
(83.7-96.2)\end{array}$ & - & $\begin{array}{c}7.9 \\
(2.0-21.5)\end{array}$ & $\begin{array}{l}89.5 \\
(75 \cdot 3- \\
96.4)\end{array}$ & $\begin{array}{c}89.5 \\
(75.3-96.4)\end{array}$ \\
\hline
\end{tabular}

CI: confidence interval; NA: not available or not applicable; NS: non-structural protein; RT-PCR: reverse transcription-PCR; ZIKV: Zika virus.

a This group contains 10 sera from residents of the Netherlands who were born and raised in Suriname and/or had visited their country of origin occasionally.

${ }^{b}$ Referring to the total number of samples in the respective patient group during the indicated sampling period.

' Referring to the whole study population of ZIKV-infected patients, i.e. samples (one per patient) taken between day 1 and day 88 post symptom onset, representing the initial (day 1-5 post symptom onset), active (day 6-20) and late phase (>20 days) of infection.

d Samples (one per patient) taken between day 6 and day 88 post symptom onset, representing the active (day 6 to 20 post symptom onset) and late phase (>20 days post symptom onset) of infection [28].

e Group 3 is not represented in the sampling period $\geq 6$ days post symptom onset, because the sampling date was available for only four out of a total of 26 samples in this group.

flavivirus) infections should be included in further assessments, as these samples have a potential for increased cross-reactivity. Future studies should also address a comparison of cross-reactivity with acute vs convalescent anti-DENV-positive samples, considering that the extent of cross-reactivity may be influenced by the level of circulating DENV-NS1 antigen-binding DENV-NS1 antibodies. Analysis of all potentially crossreactive specimens resulted in positive rates of $0.8 \%$ (IgM) and $0.4 \%$ (IgG) caused by one case each with WNV and PLAS with low-level anti-ZIKV IgM and one JEV case with low-level anti-ZIKV IgG. In these cases, however, double infections cannot be excluded, so it remains unclear if ELISA positivity resulted from the presence of ZIKV antibodies due to co-infection with ZIKV (true-positive) or from cross-reactivity (falsepositive). In case of PLAS infection, PLAS-induced polyclonal B-cell activation may cause the production of potentially cross-reactive antibodies [33]. Among patients with current PLAS infection, up to $30 \%$ false-positive or borderline reactions were reported using the presented NS1-based ELISA [34], which is in contrast to only $1.4 \%$ in the present study and probably explained by the fact that our cohort was comprised mainly of individuals with past PLAS infection status. Possible interferences should thus be considered when applying the assay.

In sera from travellers returning from ZIKV-endemic areas, we observed a tendency of ZIKV-specific IgM to appear at high ratios during the active phase of infection, paralleled by a moderate rise in IgG. In contrast, most residents in endemic areas had high anti-ZIKV $\lg G$ and low/negative IgM ratio values, irrespective of whether their samples were taken during the initial, active or late phase of infection. IgM responses in travellers returning from ZIKV-endemic areas tended to be higher compared with residents in such areas, whereas the IgG-positivity rate was higher in the latter subgroup. Such differences in ZIKV antibody kinetics were 
TABLE 4

Anti-ZIKV reactivity in potentially cross-reactive specimens $(\mathrm{n}=252)$ and healthy controls $(\mathrm{n}=1,015)$ as determined by ELISA for IgM and IgG, study evaluating a novel NS1-based ELISA, Germany 2016

\begin{tabular}{|c|c|c|c|c|c|c|}
\hline \multirow{2}{*}{ Cohort } & \multirow{2}{*}{ Characteristics } & & \multicolumn{2}{|c|}{ Prevalence \% (Cl 95\%) } & \multicolumn{2}{|c|}{ Specificity $(\mathrm{Cl} 95 \%)^{c}$} \\
\hline & & & $\lg M$ & $\operatorname{lgG}$ & $\lg M$ & $\lg G$ \\
\hline DENVa & $\begin{array}{l}\text { Dengue virus infection (high } \\
\text { median anti-DENV } \operatorname{lgM})^{\mathrm{a}}\end{array}$ & 47 & $0(0-9.0)$ & $0(0-9.0)$ & $100(91.0-100)$ & $100(91.0-100)$ \\
\hline DENVb & $\begin{array}{l}\text { Dengue virus infection (high } \\
\text { median anti-DENV IgG }\end{array}$ & 46 & $0(0-9.2)$ & $0(0-9.2)$ & $100(90.8-100)$ & $100(90.8-100)$ \\
\hline YFV & Yellow fever virus vaccination & 12 & $0(0-28.2)$ & $0(0-28.2)$ & $100(71.8-100)$ & $100(71.8-100)$ \\
\hline WNV & West Nile virus infection & 34 & $2.9(0-16.2)$ & $0(0-12.1)$ & $97.1(83.8-100)$ & $100(87.9-100)$ \\
\hline JEV & $\begin{array}{l}\text { Japanese encephalitis virus } \\
\text { infection }\end{array}$ & 25 & $0(0-15.8)$ & $4.0(0-21.1)$ & $100(84 \cdot 2-100)$ & $96.0(78.9-100)$ \\
\hline CHIKV & Chikungunya virus infection & 19 & $0(0-19.8)$ & $0(0-19.8)$ & $100(80.2-100)$ & $100(80.2-100)$ \\
\hline PLAS & Plasmodium spp. Infection & 69 & $1.4(0-8.5)$ & $0(0-6.3)$ & $98.6(91.5-100)$ & $100(93.7-100)$ \\
\hline Total & $\begin{array}{c}\text { Potentially cross-reactive } \\
\text { samples }\end{array}$ & 252 & $0.8(0-3.0)$ & $0.4(0-2.4)$ & $99.2(97.0-100)$ & $99.6(97.6-100)$ \\
\hline PREG & German pregnant women & 100 & $0(0-4.4)$ & $0(0-4.4)$ & $100(95.6-100)$ & $100(95.6-100)$ \\
\hline ZIM & Zimbabwean blood donors & 128 & $0(0-3 \cdot 5)$ & $0(0-3.5)$ & $100(96.5-100)$ & $100(96.5-100)$ \\
\hline ARG & Argentinian blood donors & 99 & $1.0(0-6.1)$ & $0(0-4 \cdot 5)$ & $99.0(94.0-100)$ & $100(95 \cdot 5-100)$ \\
\hline US & US-American blood donors & 100 & $0(0-4 \cdot 4)$ & $1.0(0-6.0)$ & $100(95.6-100)$ & $99.0(94.0-100)$ \\
\hline GER & German blood donors & 500 & $0.2(0-1.2)$ & $0.2(0-1.2)$ & $99.8(98.8-100)$ & $99.8(98.8-100)$ \\
\hline $\mathrm{CHIL}$ & German children & 88 & $0(0-5.0)$ & $0(0-5.0)$ & $100(95.0-100)$ & $100(95.0-100)$ \\
\hline Total & Healthy control samples & 1,015 & $0.2(0-0.8)$ & $0.2(0-0.8)$ & $99.8(99.2-100)$ & $99.8(99.2-100)$ \\
\hline
\end{tabular}

ARG: Argentina; CHIKV: chikungunya virus; CHIL: children; DENV: dengue virus; GER: Germany; JEV: Japanese encephalitis virus; PLAS:

Plasmodium; PREG: pregnant women; US: United States; WNV: West Nile virus; YFV: yellow fever virus; ZIKV: Zika virus; ZIM: Zimbabwe.

a Median anti-DENV IgM ratio 3.9 (79\% of samples with anti-DENV IgM ratio $\geq 3.0$ ), as indicated in the inset of Figure $2 \mathrm{~A}$.

${ }^{b}$ Median anti-DENV IgG ratio 3.9 ( $80 \%$ of samples with anti-DENV IgG ratio $\left.\geq 3.0\right)$, as indicated in the inset of Figure $2 \mathrm{~B}$.

' Referring to the total number of samples in the individual cohorts.

also illustrated by time course analysis of antibody levels in two representative patients, possibly reflecting that travellers returning from ZIKV-endemic countries predominantly had a primary flavivirus/ZIKV infection, while most residents probably contracted ZIKV as a secondary flavivirus infection. Similar kinetics have been described for primary and secondary infections in the Micronesian ZIKV epidemic [6] and for DENVinfected patients [35,36], suggesting that the detection of both specific IgM and IgG is diagnostically important and relevant for differentiating primary from secondary infections. Regarding our comparison of patients residing in endemic countries vs travellers, however, systematic differences in the background of these populations (e.g. genetic, ethnic) cannot be excluded.

Another limitation of our study is that it does not comprise side-by-side testing with additional assays, such as the Zika MAC-ELISA (Centers for Disease Control and Prevention (CDC), Atlanta, Georgia, US) or PRNT, to provide comparative data on these current tests. In addition, the non-deliberate absence of a uniform serological reference standard for the pre-characterisation of all ZIKV samples resulted in a high number of suspected cases of ZIKV infection.

Although ZIKV usually causes rather mild infections, there has been convincing evidence of a causal link to neuronal impairment, such as newborn microcephaly and GBS [37]. Furthermore, there have been studies showing that DENV NS1 antibodies have the potential of inducing autoantibodies in secondary infections, probably mediated by cross-reactive binding of antigens on platelets and endothelial cells, followed by cellular damage and inflammatory activation [17]. Basic research is needed to fully elucidate the causal relations between neuronal disorders and ZIKV infection. Epidemiologic assessment of pregnant women and their babies, and of travellers returning from endemic areas, the surveillance of donated blood and the investigation of ZIKV prevalence in endemic and nonendemic areas may provide crucial information. These studies need reliable, fast, and easy-to-handle diagnostic tests that have low cross-reactivity and allow a definite diagnosis.

In conclusion, our study revealed that the NS1-based anti-ZIKV ELISA is a sensitive and highly specific tool for the serodiagnosis of ZIKV infections, eliminating cross-reactions with antibodies to DENV and other flaviviurses. The assay format is suitable for use in routine laboratories worldwide enabling high-throughput testing in epidemic settings. Serological identification of ZIKV infections is maximised by parallel testing for $\lg M$ and $\lg G$. Further studies will be necessary to determine the accuracy of this and other current assays in a 
larger set of well-defined samples, and to clarify how ZIKV infection triggers GBS, newborn microcephaly and other neurological manifestations.

\section{${ }^{\star}$ Erratum}

The title of the $y$-axis in Figure $2 \mathrm{~B}$ was corrected to read 'Anti-Zika virus IgG ELISA (ratio)' on 22 December 2016

\section{Acknowledgements}

The authors would like to thank Jana Böthfür, Dr Babette Oesterreich, Dr Oliver Klemens, Nadja Wilhelm, Stephan Zitzewitz, and Ronald Müller for their excellent technical assistance.

This study was sponsored and funded by EUROIMMUN. Company staff were involved in study design, data collection, data analysis, data interpretation, and writing of the report. However, the contributions of EUROIMMUN employees and board members were based exclusively on scientific grounds and transparent to and reviewable by all co-authors. The corresponding author had full access to all the data in the study and had final responsibility for the decision to submit for publication.

\section{Conflict of interest}

$\mathrm{KS}, \mathrm{CP}, \mathrm{CR}$, JMW, EL, LK, AD, and SS are employees of EUROIMMUN AG. WSt and WSch are board members of EUROIMMUN AG. All other authors declare no competing interests.

\section{Authors' contributions}

This study was designed, supervised and coordinated by KS, WSt, and WSch. All authors provided important intellectual input at different stages of the work. KS, JSC, PE, MVE, JS, MPG, AG, JMW and EL contributed to the collection and, in part, pre-characterisation of patient samples. KS, CP, CR, LK, $A D$, WSt, and WSch contributed to assay development. KS and EL prepared and conducted all antibody determinations. The manuscript draft was written by JMW, AD and SS, including the analysis, statistical evaluation, and interpretation of all final data. All authors contributed to the writing of, and approved the final version of the manuscript.

\section{References}

1. European Centre for Disease Prevention and Control (ECDC) Rapid risk assessment: Zika virus epidemic in the Americas: potential association with microcephaly and Guillain-Barré syndrome. Stockholm: ECDC; 10 Dec 2015. Available from: http://ecdc.europa.eu/en/publications/Publications/zikavirus-americas-association-with-microcephaly-rapid-riskassessment.pdf

2. Fauci AS, Morens DM. Zika Virus in the Americas--Yet Another Arbovirus Threat.N Engl J Med. 2016;374(7):601-4. DOI: 10.1056/NEJMp1600297 PMID: 26761185

3. European Centre for Disease Prevention and Control (ECDC). Zika virus outbreak in the America's and the pacific: epidemiological situation 20 may 2016. Stockholm: ECDC; 2016. Available from: http://ecdc.europa.eu/en/healthtopics/ zika_virus_infection/zika-outbreak/Pages/epidemiologicalsituation.aspx

4. Duffy MR, Chen TH, Hancock WT, Powers AM, Kool JL, Lanciotti RS, et al. Zika virus outbreak on Yap Island, Federated States of Micronesia. N Engl J Med. 2009;36o(24):2536-43. DOI: 10.1056/NEJMoao805715 PMID: 19516034
5. Gould EA, Solomon T. Pathogenic flaviviruses.Lancet. 2008:371(9611):500-9. DOI: 10.1016/S0140-6736(08)60238-X PMID: 18262042

6. Lanciotti RS, Kosoy OL, Laven JJ, Velez JO, Lambert AJ, Johnson AJ, et al. Genetic and serologic properties of Zika virus associated with an epidemic, Yap State, Micronesia, 2007. Emerg Infect Dis. 2008;14(8):1232-9. DOI: 10.3201/ eid1408.080287 PMID: 18680646

7. Cao-Lormeau VM, Blake A, Mons S, Lastère S, Roche C, Vanhomwegen J, et al. Guillain-Barré Syndrome outbreak associated with Zika virus infection in French Polynesia: a case-control study. Lancet. 2016;387(10027):1531-9. DOI: 10.1016/S0140-6736(16)00562-6 PMID: 26948433

8. Martines RB, Bhatnagar J, Keating MK, Silva-Flannery L, Muehlenbachs A, Gary J, et al. Notes from the Field: Evidence of Zika Virus Infection in Brain and Placental Tissues from Two Congenitally Infected Newborns and Two Fetal Losses--Brazil, 2015. MMWR Morb Mortal Wkly Rep. 2016;65(6):159-60. DOI: 10.15585/mmwr.mm6506e1 PMID: 26890059

9. Mlakar J, Korva M, Tul N, Popović M, Poljšak-Prijatelj M, Mraz J, et al. Zika Virus Associated with Microcephaly. N Engl Med. 2016;374(10):951-8. DOI: 10.1056/NEJMoa1600651 PMID 26862926

10. Johansson MA, Mier-y-Teran-Romero L, Reefhuis J, Gilboa SM, Hills SL. Zika and the Risk of Microcephaly.N Engl J Med. 2016;375(1):1-4. DOI: 10.1056/NEJMp1605367 PMID: 27222919

11. Bingham AM, Cone M, Mock V, Heberlein-Larson L, Stanek D, Blackmore C, et al. Comparison of Test Results for Zika Virus RNA in Urine, Serum, and Saliva Specimens from Persons with Travel-Associated Zika Virus Disease - Florida, 2016. MMWR Morb Mortal Wkly Rep. 2016;65(18):475-8. DOI: 10.15585/ mmwr.mm6518e2 PMID: 27171533

12. Reusken C, Pas S. GeurtsvanKessel C, Mögling R, van Kampen J, Langerak T, et al. Longitudinal follow-up of Zika virus RNA in semen of a traveller returning from Barbados to the Netherlands with Zika virus disease, March 2016. Euro Surveill. 2016;21(23):30251. PMID: 27313200

13. Gourinat AC, O'Connor O, Calvez E, Goarant C, DupontRouzeyrol M. Detection of Zika virus in urine.Emerg Infect Dis. 2015;21(1):84-6. DOI: 10.3201/eid2101.140894 PMID: 25530324

14. Corbett KS, Katzelnick L, Tissera H, Amerasinghe A, de Silva $A D$, de Silva AM. Preexisting neutralizing antibody responses distinguish clinically inapparent and apparent dengue virus infections in a Sri Lankan pediatric cohort.J Infect Dis. 2015;211(4):590-9. DOI: 10.1093/infdis/jiu481 PMID: 25336728

15. Puschnik A, Lau L, Cromwell EA, Balmaseda A, Zompi S, Harris E. Correlation between dengue-specific neutralizing antibodies and serum avidity in primary and secondary dengue virus 3 natural infections in humans.PLoS Negl Trop Dis. 2013;7(6):e2274. DOI: 10.1371/journal.pntd.0002274 PMID: 23785536

16. Lindenbach BD, Rice CM. Molecular biology of flaviviruses.Adv Virus Res. 2003;59:23-61. DOI: 10.1016/S0065-3527(03)590029 PMID: 14696326

17. Muller DA, Young PR. The flavivirus NS1 protein: molecular and structural biology, immunology, role in pathogenesis and application as a diagnostic biomarker.Antiviral Res. 2013;98(2):192-208. DOI: 10.1016/j.antiviral.2013.03.008 PMID: 23523765

18. MacKenzie JM, Jones MK, Young PR. Immunolocalization of the dengue virus nonstructural glycoprotein NS1 suggests a role in viral RNA replication.Virology. 1996;220(1):232-40. DOI: 10.1006/viro.1996.0307 PMID: 8659120

19. Winkler G, Randolph VB, Cleaves GR, Ryan TE, Stollar V. Evidence that the mature form of the flavivirus nonstructural protein NS1 is a dimer.Virology. 1988;162(1):187-96. DOI: 10.1016/0042-6822(88)90408-4 PMID: 2827377

20. Flamand M, Megret F, Mathieu M, Lepault J, Rey FA, Deubel V. Dengue virus type 1 nonstructural glycoprotein NS1 is secreted from mammalian cells as a soluble hexamer in a glycosylationdependent fashion.J Virol. 1999;73(7):6104-10.PMID: 10364366

21. Brown WC, Akey DL, Konwerski JR, Tarrasch JT, Skiniotis G, Kuhn RJ, et al. Extended surface for membrane association in Zika virus NS1 structure. Nat Struct Mol Biol. 2016;23(9):865-7. DOI: $10.1038 / n s m b .3268$ PMID: 27455458

22. Lee JM, Crooks AJ, Stephenson JR. The synthesis and maturation of a non-structural extracellular antigen from tick-borne encephalitis virus and its relationship to the intracellular NS1 protein.J Gen Virol. 1989;70(Pt 2):335-43. DOI: 10.1099/0022-1317-70-2-335 PMID: 2471787

23. Alcon S, Talarmin A, Debruyne M, Falconar A, Deubel V, Flamand M. Enzyme-linked immunosorbent assay specific to Dengue virus type 1 nonstructural protein NS1 reveals circulation of the antigen in the blood during the acute phase of disease in patients experiencing primary or secondary 
infections.J Clin Microbiol. 2002;40(2):376-81. DOI: 10.1128/ JCM.40.02.376-381.2002 PMID: 11825945

24. Macdonald J, Tonry J, Hall RA, Williams B, Palacios G, Ashok $M S$, et al. NS1 protein secretion during the acute phase of West Nile virus infection. J Virol. 2005;79(22):13924-33. DOI: 10.1128/JVI.79.22.13924-13933.2005 PMID: 16254328

25. Matheus S, Boukhari R, Labeau B, Ernault V, Bremand L, Kazanji M, et al. Specificity of Dengue NS1 Antigen in Differential Diagnosis of Dengue and Zika Virus Infection. Emerg Infect Dis. 2016;22(9):1691-3. DOI: 10.3201/ eid2209.160725 PMID: 27347853

26. Cleton NB, Godeke GJ, Reimerink J, Beersma MF, Doorn HR, Franco L, et al. Spot the difference-development of a syndrome based protein microarray for specific serological detection of multiple flavivirus infections in travelers. PLoS Negl Trop Dis. 2015;9(3):eoo03580. DOI: 10.1371/journal. pntd.oo03580 PMID: 25767876

27. Huzly D, Hanselmann I, Schmidt-Chanasit J, Panning M. High specificity of a novel Zika virus ELISA in European patients after exposure to different flaviviruses. Euro Surveill. 2016;21(16):30203. DOI: 10.2807/1560-7917 ES.2016.21.16.30203 PMID: 27126052

28. Pan American Health Organization, World Health Organization (WHO). Zika virus (ZIKV) Surveillance in the Americas: Interim guidance for laboratory detection and diagnosis. 2015. Available from: http://iris.paho.org/xmlui/bitstream/ handle/123456789/18602/zikavirusinterim_jan2015. pdf? sequence $=1$ \&isAllowed $=y$

29. Zentrale Ethikkommission bei der Bundesärztekammer. Die (Weiter-) Verwendung von menschlichen Körpermaterialien für Zwecke der medizinischen Forschung (2003) [The (further) use of human body samples for the purpose of medical research (2003)]: Berlin: Zentrale Ethikkommussion bei der Bundesärztekammer. Available from: http://www.zentraleethikkommission.de/downloads/Koerpermat.pdf

30. Bossuyt PM, Reitsma JB, Bruns DE, Gatsonis CA, Glasziou PP, Irwig L, et al. , STARD Group. STARD 2015: an updated list of essential items for reporting diagnostic accuracy studies.BMJ. 2015;351:h5527. DOI: 10.1136/bmj.h5527 PMID: 26511519

31. Gyurech D, Schilling J, Schmidt-Chanasit J, Cassinotti P, Kaeppeli F, Dobec M. False positive dengue NS1 antigen test in a traveller with an acute Zika virus infection imported into Switzerland.Swiss Med Wkly. 2016;146:W14296.PMID: 26859285

32. Rubin EJ, Greene MF, Baden LR. Zika Virus and Microcephaly.N Engl J Med. 2016;374(10):984-5. DOI: 10.1056/NEJMe1601862 PMID: 26862812

33. Scholzen A, Sauerwein RW. How malaria modulates memory: activation and dysregulation of B cells in Plasmodium infection.Trends Parasitol. 2013;29(5):252-62. DOI: 10.1016/j. pt.2013.03.002 PMID: 23562778

34. Van Esbroeck M, Meersman K, Michiels J, Arien KK, Van den Bossche D. Letter to the editor: Specificity of Zika virus ELISA: interference with malaria. Euro Surveill. 2016;21(21). http:// dx.doi.org/DOI: 10.2807/1560-7917.ES.2016.21.21.30237

35. Vaughn DW, Green S, Kalayanarooj S, Innis BL, Nimmannitya S, Suntayakorn S, et al. Dengue in the early febrile phase: viremia and antibody responses. J Infect Dis. 1997;176(2):32230. DOI: $10.1086 / 514048$ PMID: 9237696

36. Sa-Ngasang A, Anantapreecha S. A-Nuegoonpipat A, Chanama S, Wibulwattanakij S, Pattanakul K, et al. Specific IgM and IgG responses in primary and secondary dengue virus infections determined by enzyme-linked immunosorbent assay. Epidemiol Infect. 2006;134(4):820-5. PMID: 16371180

37. World Health Organization (WHO). Zika virus-Fact sheet. Updated 6 September 2016. Geneva: WHO. [Accessed 9 Dec 2016]. Available from: http://www.who.int/mediacentre/ factsheets/zika/en/

\section{License and copyright}

This is an open-access article distributed under the terms of the Creative Commons Attribution (CC BY 4.0) Licence. You may share and adapt the material, but must give appropriate credit to the source, provide a link to the licence, and indicate if changes were made.

This article is copyright of the authors, 2016. 